\title{
Pendidikan Kesehatan (Buku KIA 2020) Khusus Ibu di Masa Pandemi Covid-19 di PMB Bumi Cinta Gorontalo
}

\author{
${ }^{1}$ Efri Leny Rauf, ${ }^{2}$ Dwi Nur Octaviani Katili, ${ }^{3}$ Siskawati Umar \\ 1,2;3Program Studi Pendidikan Profesi Bidan, Fakultas IImu Kesehatan,Universitas Muhammadiyah Gorontalo \\ Korespondensi: efryleniraufbidan2021@gmail.com
}

\begin{abstract}
Abstrak: Pengetahuan ibu tentang penggunaan buku Kesehatan Ibu dan Anak (KIA) masih dianggap hanya sebagai buku pencatatan kesehatan bagi petugas, hal ini menjadi kendala dalam pembentukan perilaku kesehatan ibu hamil tentang pentingya melakukan periksa kehamilan secara rutin, memahami tanda bahaya kehamilan secara dini, pentingya minum tablet $\mathrm{Fe}$ secara teratur, serta perawatan kesehatan sehari-hari. Menurut survei awal tim pengabdian, kami melihat bahwa pengetahuan dan pemahaman berdampak pada kesadaran dari ibu hamil tentang isi buku KIA terutama saat ini buku KIA sudah di revisi terbaru sehingga pentingnya pendidikan kesehatan buku KIA perlu di jelaskan lagi di praktek mandiri bidan bumi cinta gorontalo. Metode pengabdian yakni dengan ceramah/ penyuluhan, diskusi dan tanya jawab. Hasil pengabdian, kami mendapatkan antusias ibu hamil dalam menyimak penjelasan dari kami dan bertanya hal-hal yang penting mereka ingin ketahui. Kata Kunci :Buku, Kesehatan Ibu dan Anak, Pendidikan.
\end{abstract}

\begin{abstract}
Knowledge of mothers about the use of Maternal and Child Health (MCH) books, which is still considered only as a health record book for health workers, is an obstacle in shaping the health behavior of pregnant women about the importance of routine pregnancy check-ups, understanding the danger signs of early pregnancy, the importance of taking Fe tablets regularly, as well as daily health care. According to the initial survey of the service team, we see that knowledge and understanding have an impact on the awareness of pregnant women about the contents of the $\mathrm{MCH}$ book, especially now that the $\mathrm{MCH}$ book has been revised so that the importance of health education on $\mathrm{MCH}$ books needs to be explained again in the independent practice of the midwife of the love of Gorontalo. The method of service is through lectures/counseling, discussion and question and answer. As a result of our dedication, we get the enthusiasm of pregnant women in listening to our explanations and asking important things they want to know
\end{abstract}

Keywords :Book, Health of both Mother and Child, Education.

\section{PENDAHULUAN}

Pengetahuan ibu tentang penggunaan buku Kesehatan Ibu dan anak (KIA) masih sangat kurang, ini terbukti banyak diantara mereka menganggap itu hanya buku biasa, hal ini menjadi tantangan tersendiri bagi petugas kesehatan dan bahkan menjadi kendala dalam pembentukan perilaku kesehatan ibu hamil tentang pentingya melakukan periksa kehamilan secara rutin, memahami tanda bahaya kehamilan secara dini, pentingya minum tablet Fe secara teratur, serta perawatan kesehatan sehari-hari ${ }^{1}$.

Buku KIA merupakan Buku catatan terpadu yang digunakan dalam keluarga dengan tujuan meningkatkan praktik keluarga dalam perawatan kesehatan Ibu dan Anak ${ }^{2}$. Peningkatan implementasi buku Kesehatan Ibu dan Anak (KIA) didukung oleh pemerintah pusat sebagai salah satu program untuk meningkatkan kesehatan Ibu dan Anak, menuntun petugas kesehatan memberikan pelayanan kesehatan ibu dan anak sesuai standart, melakukan dokumentasi secara baik dan benar, serta merupakan satu satunya bukti yang dipegang ibu sebagai dokumentasi status kesehatanya selama hamil, bersalin, nifas, imunisasi dan tumbuh kembang balita, sehingga mempermudah ibu dan keluarga serta petugas kesehatan mengetahui riwayat kesehatan ibu dan anak ${ }^{3}$.

KIA juga merupakan alat komunikasi dan media informasi yang penting bagi tenaga kesehatan, ibu hamil, keluarga dan masyarakat, yang berfungsi sebagai alat untuk mengetahui status kesehatan ibu hamil, dokumentasi, deteksi dini adanya resiko, Konseling, serta untuk memantau tumbuh kembang balita 4 .

This is an open-access article under the CC BY 4.0 International License

(C) Idea PengabdianMasyarakat (2021)

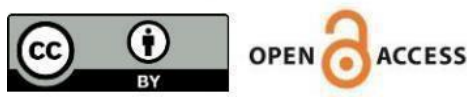




\section{METODE PELAKSANAAN}

\section{Tahap 1 Pembukaan}

a. salam pembuka

b. penjelasan tujuan pembelajaran

c. menyebutkan poin pokok pembahasan

\section{Tahap II Pelaksanaan}

Menjelaskan materi berupa kunjungan kehamilan, gizi dan Ibu Hamil dan tanda bahaya kehamilan

\section{Tahap III Evaluasi}

Meminta kembali Ibu Hamil untuk menjelaskan kesimpulan dengan caranya masing-masing agara mengetahui sampai dimana pengetahuan Ibu Hamil.

Kriteria Evaluasi

a. Evaluasi Struktur

1. Ibu hamil ikut dalam kegiatan pendidikan kesehatan buku KIA

2.Penyelenggaraan penyuluhan di lakukan di Praktek Mandiri Bidan Bumi Cinta Gorontalo

3. Pengorganisasian penyuluhan dilakukan 2 hari sebelumnya

b. Evaluasi Proses

1.Ibu hamil antusias terhadap materi pendidikan kesehatan yang disampaikan

2.Ibu hamil melihat buku KIA masing-masing yang mereka miliki

3.Ibu hamil mengikuti proses sampai selesai kegiatan

4.Ibu hamil aktif berkomunikasi saat kegiatan berlangsung

c. Evaluasi Hasil

1.Ibu hamil mengetahui dengan baik tentang buku KIA

2.Ibu hamil mengetahui manfaat setelah dijelaskan isi buku KIA

\section{HASIL DAN PEMBAHASAN}

Pengetahuan Ibu hamil tentang pemanfaatan Buku KIA memang sangat penting, penelitian Hanum juga mengungkapkan temuan tersebut yakni adanya Hubungan pengetahuan Ibu Hamil dengan pemanfaatan Buku KIA di Puskesmas Namu Ukur, penelitian ini juga menyarankan kepada Petugas Kesehatan untuk rutin memberikan penyuluhan kesehatan mengenai pemeriksaan usia kandungan dan hal lain yang berkaitan dengan kesehatan Ibui Hamil 5 .

Penelitian lain juga membuktikan bahwa pengetahuan Ibu bukan hanya bermanfaat saat proses kehamilan namun setelah kelahiran Anak pengetahuan juga berkontribusi dalam mendukung Ibu menyusui dengan ASI Eksklusif6.

Pengabdian Masyarakat ini banyak memberikan pengetahuan tambahan kepada Ibu hamil terutama dengan pendekatan yang dilakukan yakni opemberian materi trekhusus Buku KIA dan yang berkaitan dengan pentingnya kunjungan kehamilan ke fasilitas kesehatan.

Ibu Hamil yang terlibat dalam pengabdian Masyarakat ini sangat antusias dalam mendengarkan materi yang disampaikan oleh narasumber, ini dapat dilihat dengan tindakan langsung mereka dengan membaca Buku KIA yang dipegangnya, selain itu disela sela kegiatan mereka terkadang bertanya dan memberikan feedback kepada Narasumber.

Pengetahuan yang baik akan memberikan dampak positif terhadap pemanfaatan BUKU KIA ${ }^{7}$. selain itu dukungan keluarga terdekat misalnya Orang Tua, Suami dan Ibu juga berkontribusi ${ }^{8}$. Sikap positif Ibu terhadap KIA merupakan salah satu alasan yang mendorong dalam pengasuhan anak yang baik sesuai dengan informasi yang didapatkanya9.

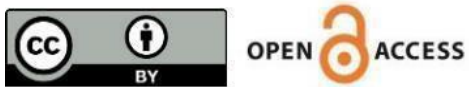



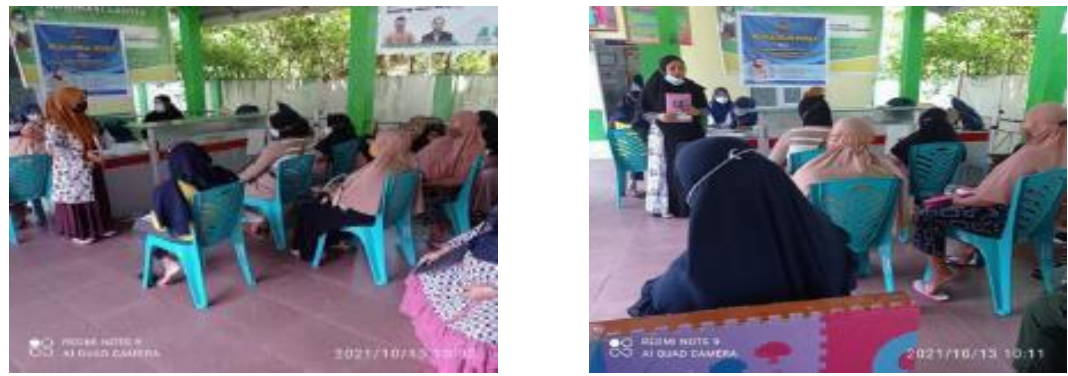

Gambar 1 dan 2. Kegiatan Penyuluhan Buku KIA

\section{KESIMPULAN}

Pengetahuan Ibu Hamil mengenai Buku KIA dan pemanfaatanya bertambah, penyuluhan harus tetap dilakukan dalam upaya terus mencegah angka kematian Ibu dan Anak. Dukungan keluarga dan Suami sangat berperan dalam memotivasi Ibu Hamil untuk terus memahami Buku KIA. Pengetahuan yang tinggi meminimalisir resiko terhadap Ibu Hamil dan calon bayinya, selain itu dapat menjadi dasar pengasuhan Anak di masa yang akan datang.

\section{UCAPAN TERIMAKASIH}

Terimakasih kepada Semua Tim dalam pengabdian termasuk Narasumber, terimakasih juga kepada Masyarakat dan Ibu Hamil yang telah mendukung dan ikut berpasitisipasi dalam kegiatan ini.

\section{DAFTAR PUSTAKA}

1. Sistiarani C, Gamelia E, Sari DUP. Fungsi Pemanfaatan Buku KIA terhadap Pengetahuan Kesehatan Ibu dan Anak pada Ibu. Kesmas Jurnal Kesehatan Masy.[cited2021Nov.26];8(08):Available from : https://media.neliti.com/media/publications/39859-ID-fungsi-pemanfaatan-buku-kia-terhadappengetahuan-kesehatan-ibu-dan-anak-pada-ibu.pdf

2. Kemenkes RI. Buku Ajar Kesehatan Ibu dan Anak. 2015; available from: http://bppsdmk.kemkes.go.id/pusdiksdmk/wp-content/uploads/2017/10/02Buku-KIA-06-10-2015small.pdf

3. Dinkes Surakarta. Gerakan Membaca Buku Kia. 2019;Available from : https://dinkes.surakarta.go.id/gerakan-membaca-buku-kia/

4. Sihole, Santosa, Lubis. Peran Tenaga Kesehatan terhadap Pengetahuan Ibu Hamil tentang Buku KIA di Puskesmas GadjahMada Tahun 2020; Available https://media.neliti.com/media/publications/330886-peran-tenaga-kesahatan-terhadap-pengetah639b6f2b.pdf

5. Hanum R, Safitri E. Hubungan pengetahuan dan Sikap Ibu Hamil tentang Pemanfaatan Buku KIA di Puskesmas Namu Ukur. Jurnal Bidan Komunitas [Internet].2018Sept[cited2021Nov.26];1(03):152-60. Available from: http://ejournal.helvetia.ac.id/index.php/jbk/article/view/3968/138

6. Rachmaniah M. Hubungan Tingkat Pengetahuan Ibu tentang ASI dengan Tindakan ASI Eksklusif. Universitas Muhammadiyah Yogyakarta. 2014.

7. Kusmiyanti. Perawatan Ibu Hamil.Yogyakarta:Fitramaya:2013

8. Wardani, Purwanti. Perilaku Penggunaan Buku Kesehatan Ibu dan Anak (KIA) pada Ibu hamil di Wilayah Kerja Puskesmas Kecamatan Sragen. Universitas Muhammadiyah Surakarta;2018.

9. Mahayati, Hernowo, Judistiani. Pengetahuan, Sikap, dan Praktik Penggunaan Buku Kesehatan Ibu dan Anak pada Anak Umur Usia 35 Tahun di Kota Denpasar;2014.

This is an open-access article under the CC BY 4.0 International License

(C) Idea PengabdianMasyarakat (2021)

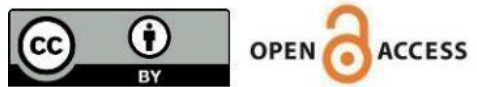

